\title{
Response of Cotton to Different Tillage Depth and Irrigation Levels in Southern Gujarat, India
}

\author{
V.T. Bagal, A.J. Madane*, R.A. Gaikwad, R.R. Sisale, \\ P.U. Lawate, V. Akhilesh and J.K. Singh \\ Department of Agronomy, Banaras Hindu University, Varanasi -221 005, India \\ *Corresponding author
}

\begin{tabular}{l} 
Key w or d s \\
$\begin{array}{l}\text { Cotton, Tillage, } \\
\text { Irrigation, Seed } \\
\text { cotton yield }\end{array}$ \\
Article Info \\
\hline $\begin{array}{l}\text { Accepted: } \\
\text { 07 January } 2018 \\
\text { Available Online: } \\
\text { 10 February } 2018\end{array}$ \\
\hline
\end{tabular}

A B S T R A C T

A field experiment was conducted during Kharif season of 2008-2009 at the Main Cotton Research Station, Surat, Navsari. The soil of an experimental field was clayey in texture, medium in available nitrogen $\left(297.9 \mathrm{~kg} \mathrm{ha}^{-1}\right)$, medium in available phosphorus $(49.19 \mathrm{~kg}$ $\mathrm{ha}^{-1}$ ) and fairly rich in available potassium (528.5 kg ha ${ }^{-1}$ ) with $7.5 \mathrm{pH}$. The experiment was conducted in split plot design, comprising three tillage depth in main plot viz. normal tillag eup to7.5 $\mathrm{cm}(\mathrm{Di})$, tillage up to $15 \mathrm{~cm}\left(\mathrm{D}_{2}\right)$ and tillage up to $22.5 \mathrm{~cm}\left(\mathrm{D}_{3}\right)$ and three irrigation levels in sub plot viz. two irrigations at 25 and 50 days after cessation of rainfall with $80 \mathrm{~mm}$ diw at each irrigation $\left(\mathrm{I}_{2}\right)$, two irrigations at 25 and 75 days after cessation of rainfall with $60 \mathrm{~mm}$ diw at each irrigation $\left(\mathrm{I}_{2}\right)$ and three irrigations at 25, 50 and 75 days after cessation of rainfall with $60 \mathrm{~mm}$ diw at each irrigation $\left(1_{3}\right)$ were evaluated in split plot design with three replications. The results revealed that seed cotton $\left(3918.90 \mathrm{~kg} \mathrm{ha}^{-1}\right)$ and stalk yields $\left(4119.12 \mathrm{~kg} \mathrm{ha}^{-1}\right)$ The per cent increase in seed cotton yield by the treatment $\mathrm{D}_{3}$ (tillage upto $22.5 \mathrm{~cm}$ ) was to the tune of 21.34 and 62.96 per cent over $\mathrm{D}_{2}$ (tillage upto $15 \mathrm{~cm}$ ) and $D_{1}$ (tillage upto $7.5 \mathrm{~cm}$ ) treatments, respectively. The treatment $l_{3}$ (three irrigations at 25, 50 and 75 days after cessation of rainfall with $60 \mathrm{~mm}$ diw at each irrigation) produced significantly the highest seed cotton $\left(3340.31 \mathrm{~kg} \mathrm{ha}^{-1}\right)$ and stalk $\left(3686.86 \mathrm{~kg} \mathrm{ha}^{-1}\right.$ ) yields. The increase in seed cotton yield due to the treatment $\mathrm{I}_{3}$ (three irrigations at 25, 50 and 75 days after cessation of rainfall $60 \mathrm{~mm}$ diw at each irrigation) was 13.05 per cent higher over $I_{1}(25$ and 50 days after cessation of rainfall with $80 \mathrm{~mm}$ diw at each irrigation). The highest nutrient content and uptake by plant was recorded in treatment $\mathrm{I}_{3}$ (three irrigations at 25, 50 and 75 days after cessation of rainfall with $60 \mathrm{~mm}$ diwat each irrigation). On the basis of experimental results, it can be concluded that the highest seed cotton yield and maximum net profit from Kharif cotton Cv. RCH-2 can be obtained by Ploughing the soil upto $22.5 \mathrm{~cm}$ depth with application of three irrigations each of $60 \mathrm{~mm}$ depth at 25, 50 and 75 days after cessation of rainfall with recommended dose of fertilizer.

\section{Introduction}

Cotton is a natural fiber of plant origin, like linen jute or hemp. India is the traditional home of cotton and textile. Indian economy has been consistently influenced and boosted by cotton through its production and processing sectors and by generating direct 
and indirect employment to more than 8 million people. Cotton is also a vital crop of commerce popularly known as "WHITE GOLD' In South Gujarat, characterized by heavy rainfall zone and most of the farmers of this region adopted mechanical cultivation and continuous use of canal water for irrigation and use of high doses of chemical fertilizers without or very low application of organic manures in their field, thereby the soil of the South Gujarat zone was compacted with deterioration of the soil structure. Under such conditions cotton produces low yield and therefore is necessary to improve the soil health through proper soil management. For overcoming these situations, deep tillage and irrigation play a crucial role to improve soil health by increasing porosity and decreasing bulk density of soil and thereby increasing infiltration rate of the soil which increases the deep penetration of crop roots. In cotton crop, continuous wetness within rooting zone adversely affects the crop growth. Proper aeration is must for the proper function of the root growth. Therefore, irrigation scheduling based on rainfall cessation results in higher yield. Work on water requirement of cotton in India shows a wide range of results because there are several species in cotton having different life duration as well as growing seasons. Secondly, cotton being a Kharif crop in many regions the experiment is vitiated by variable rainfall pattern. Thirdly, the crop is grown on light soil as well as on heavy soils and therefore, frequency varies considerably with the soil type.

\section{Materials and Methods}

The field experiment was conducted in Cotton Research Station. Surat during the Kharif season of 2008-09. The Main Cotton Research Station, Surat is situated in South Gujarat at a cross point of $20^{\circ}-12^{\circ} \mathrm{N}$ latitude and $72^{\circ}-$ 52' longitude at elevation of 11.34 meters above the mean sea level. The average annual precipitation is $1187.7 \mathrm{~mm}$. The total rainfall recorded during the year 2008-09 amounted to $1296.1 \mathrm{~mm}$ within 51 total rainy days, respectively during the crop growth period. Drained clayey soils which represent the typical black cotton soil of South Gujarat having predominate montmorillonite clay minerals by its organ and is medium in fertility. The experiment was conducted in split plot design, comprising three tillage depth in main plot viz. normal tillage up to 7.5 $\mathrm{cm}$ (Di), tillage up to $15 \mathrm{~cm}\left(\mathrm{D}_{2}\right)$ and tillage up to $22.5 \mathrm{~cm}\left(\mathrm{D}_{3}\right)$ and three irrigation levels in sub plot viz. two irrigations at 25 and 50 days after cessation of rainfall with $80 \mathrm{~mm}$ diw at each irrigation $\left(\mathrm{I}_{2}\right)$, two irrigations at 25 and 75 days after cessation of rainfall with $60 \mathrm{~mm}$ diw at each irrigation $\left(\mathrm{I}_{2}\right)$ and three irrigations at 25, 50 and 75 days after cessation of rainfall with $60 \mathrm{~mm}$ diw at each irrigation $\left(l_{3}\right)$ were evaluated in split plot design with three replications. Cotton variety $\mathrm{RCH}-2$ was used for experiment purpose. Crop was irrigated as per treatments based on rainfall cessations through canal irrigation water. Measured quantity of irrigation water was applied though through Parshalflume.

Water expense efficiency was calculated as described by Patel (1993).

Water expense

Seed cotton yield (kg/ha) Efficiency $\left(\mathrm{Kg}\right.$ ha $\left.\mathrm{mm}^{-1}\right)=$

Total quantity of irrigation water applied

(mm)

\section{Results and Discussion}

\section{Effect of tillage depth irrigation schedule on growth attributes}

The significantly the tallest plant was observed at 120 DAS with tillage upto $22.5 \mathrm{~cm}$. Tillage depth increase root growth which favorably induces uptake of nutrients 
and water as cotton is a deep rooted crop. Water holding capacity of soil also increases with better infiltration rate. Hence, deeper the tillage, more is the quantity of water stored in the soil and water is considered as essential input for plant growth. These findings corroborate the results of Triplett et al., (1996) as well as Wiatrack et al., (2005)

The significantly the tallest plant was obtained under scheduling of irrigations at 25, 50 and 75 days after cessation of rainfall with $60 \mathrm{~mm}$ diw at each irrigation at 120 DAS stages.

Dry matter accumulation of cotton was significantly higher with scheduling of irrigations at 25, 50 and 75 days after cessation of rainfall with $60 \mathrm{~mm}$ diw at each irrigation. Water storage capacity in soil and its efficient use due to better root development and distribution resulting significantly higher plant growth. These finding are on the line with the results of Stockon et al., (1961) as well as Singh and Bhan (1993b).

\section{Effect of tillage depth and irrigation scheduling on yield attributes and yield}

Number of bolls per plant was significant and maximum value was noted under tillage depth upto $22.5 \mathrm{~cm}$ This might be due to profused vegetative growth ultimately more sympodial branches per plant provided better room for number of bolls. The results partial confirm the findings of Baker (1987), Solaiappan and Sheriff (1994) as well as Nayakatawa et al., (2000).

The significantly highest seed $(3918.90 \mathrm{~kg}$ ha1) and stalk (4119.12 kg ha-1) yields were recorded with $22.5 \mathrm{~cm}$ tillage depth. This was because of favorable effect of deep Ploughing in improvement of growth attributes such as plant height, number of bolls per plant, dry matter accumulation and sympodial branch per plant as reported by Solaiappan and
Sheriff (1994). Deep tillage improves physical condition and it would be favorable for seed germination, emergence, and nutrient availability and reduces weed population. These findings are in conformity with the results obtained by Gidda and Morey (1981), Adeoye (1982) as well as Triplett et al., (1996).

The number of boll per plant was significantly highest under scheduling of irrigations at 25, 50 and 75 days after cessation of rainfall with $60 \mathrm{~mm}$ diw at each irrigation. This may be due to right time availability of water at reproductive stage which ultimately increased the number of bolls per plant. Similar results were obtained by Singh and Bhan (1993b).

This was due to sufficient availability of water through rainfall and irrigation scheduling at appropriate time resulted in favorable effect. The result corroborated the finding of Singh and Bhan (1993b). The number of boll per plant was significantly highest under scheduling of irrigations at 25, 50 and 75 days after cessation of rainfall with $60 \mathrm{~mm}$ diw at each irrigation.

This may be due to right time availability of water at reproductive stage which ultimately increased the number of bolls per plant. Similar results were obtained by Singh and Bhan (1993b). The scheduling of three irrigations at 25,50 and 75 days after cessation of rainfall with $60 \mathrm{~mm}$ diw at each irrigation produced significantly higher seed cotton $\left(3340.31 \mathrm{~kg} \mathrm{ha}^{-1}\right)$ and stalk $(3686.86 \mathrm{~kg}$ $\mathrm{ha}^{-1}$ ) yields (Table 1). This might be due to availability of right quantity of water at right time. At vegetative growth stage of cotton crop get water from rainfall and later at reproductive stage supplemented through irrigation. These findings are in conformity with the result obtained by Palchamy et al., (1986), Khade et al., (1988), Chimanshette et al., (1990) as well as Singh and Singh (2000). 
Table.1 Effect of tillage depth and irrigation levels on growth and yield of cotton

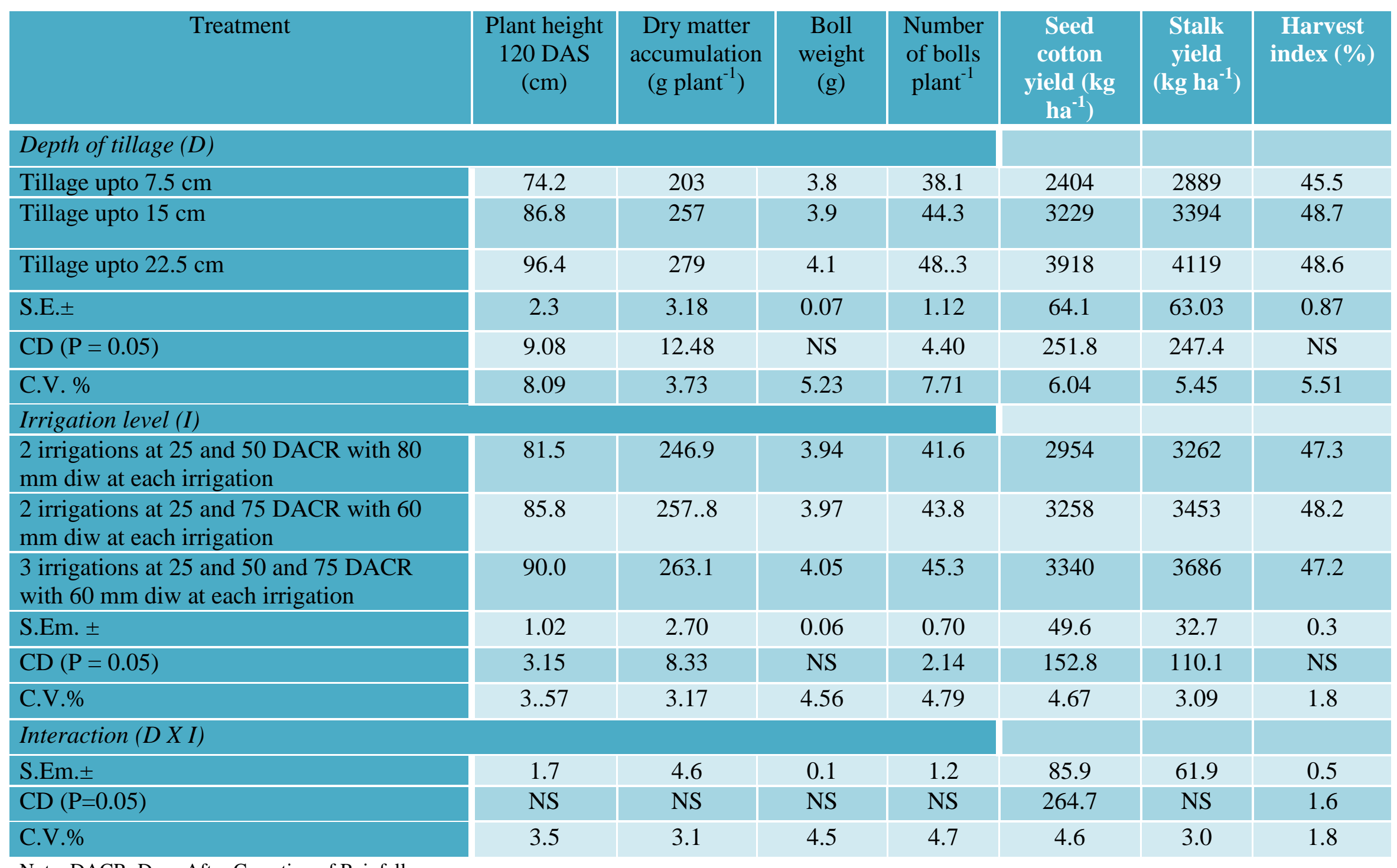

Note: DACR: Days After Cessation of Rainfall 
Table.2 Effect of tillage depth and irrigation levels on water expenses efficiency $\left(\mathrm{kg}\right.$ ha $\left.\mathrm{mm}^{1}\right)$

\begin{tabular}{|c|c|c|c|c|}
\hline Treatment & $\begin{array}{l}\text { Rainfall } \\
(\mathrm{mm})\end{array}$ & $\begin{array}{c}\text { Quantity of } \\
\text { water applied } \\
(\mathrm{mm})\end{array}$ & $\begin{array}{l}\text { Total Quantity } \\
\text { of water applied } \\
(\mathrm{mm})\end{array}$ & $\begin{array}{c}\text { water } \\
\text { expenses } \\
\text { efficiency }(\mathrm{kg} \\
\left.\text { ha } \mathrm{mm}^{1}\right)\end{array}$ \\
\hline \multicolumn{5}{|l|}{ Depth of tillage $(D)$} \\
\hline Tillage upto $7.5 \mathrm{~cm}$ & 1296.1 & - & 1296.1 & 16.50 \\
\hline Tillage upto $15 \mathrm{~cm}$ & 1296.1 & - & 1296.1 & 21.48 \\
\hline Tillage upto $22.5 \mathrm{~cm}$ & 1296.1 & - & 1296.1 & 26.88 \\
\hline S.E. \pm & - & - & - & 0.43 \\
\hline $\mathrm{CD}(\mathrm{P}=0.05)$ & - & - & - & 1.68 \\
\hline C.V. $\%$ & - & - & - & 5.99 \\
\hline \multicolumn{5}{|l|}{ Irrigation level (I) } \\
\hline $\begin{array}{l}2 \text { irrigations at } 25 \text { and } 50 \text { DACR with } 80 \mathrm{~mm} \text { diw at each } \\
\text { irrigation }\end{array}$ & 1296.1 & 160 & 1456.1 & 18.47 \\
\hline $\begin{array}{l}2 \text { irrigations at } 25 \text { and } 75 \text { DACR with } 60 \mathrm{~mm} \text { diw at each } \\
\text { irrigation }\end{array}$ & 1296.1 & 120 & 1416.1 & 27.15 \\
\hline $\begin{array}{l}3 \text { irrigations at } 25 \text { and } 50 \text { and } 75 \text { DACR with } 60 \mathrm{~mm} \text { diw at each } \\
\text { irrigation }\end{array}$ & 1296.1 & 180 & 1476.1 & 18.56 \\
\hline S.Em. \pm & - & - & - & 0.34 \\
\hline $\mathrm{CD}(\mathrm{P}=0.05)$ & - & - & - & 1.05 \\
\hline C.V.\% & - & - & - & 4.77 \\
\hline \multicolumn{5}{|l|}{ Interaction (DXI) } \\
\hline S.Em. \pm & - & - & - & 0.59 \\
\hline $\mathrm{CD}(\mathrm{P}=0.05)$ & - & - & - & 1.89 \\
\hline C.V.\% & - & - & $=$ & 4.77 \\
\hline
\end{tabular}


Table.3 Interaction effect tillage depth and irrigation levels on seed cotton yield and stalk yield $\left(\mathrm{kg} \mathrm{ha}^{-1}\right)$

\begin{tabular}{|c|c|c|c|}
\hline Treatment & $\begin{array}{l}\text { Tillage up to } \\
7.5 \mathrm{~cm}\end{array}$ & Tillage up to $15 \mathrm{~cm}$ & Tillage up to $22.5 \mathrm{~cm}$ \\
\hline $\begin{array}{l}2 \text { irrigations at } 25 \text { and } 50 \text { DACR with } 80 \mathrm{~mm} \text { diw at } \\
\text { each irrigation }\end{array}$ & 2190 & 3083 & 3590 \\
\hline $\begin{array}{l}2 \text { irrigations at } 25 \text { and } 75 \text { DACR with } 60 \mathrm{~mm} \text { diw at } \\
\text { each irrigation }\end{array}$ & 2361 & 3436 & 3976 \\
\hline $\begin{array}{l}3 \text { irrigations at } 25 \text { and } 50 \text { and } 75 \text { DACR with } 60 \mathrm{~mm} \\
\text { diw at each irrigation }\end{array}$ & 2662 & 3168 & 4189 \\
\hline S. Em. \pm & \multicolumn{3}{|c|}{85.9} \\
\hline $\mathrm{CD}(\mathrm{P}=0.05)$ & \multicolumn{3}{|c|}{264.7} \\
\hline C.V.\% & \multicolumn{3}{|c|}{4.67} \\
\hline
\end{tabular}

Note: DACR: Days After Cessation of Rainfall

Table.4 Effect of tillage depth and irrigation levels on water expenses efficiency $\left(\mathrm{kg} \mathrm{ha} \mathrm{mm}{ }^{-1}\right)$ of cotton

\begin{tabular}{|c|c|c|c|}
\hline Treatment & $\begin{array}{c}\text { Tillage up to } 7.5 \\
\mathrm{~cm}\end{array}$ & Tillage up to $15 \mathrm{~cm}$ & Tillage up to $22.5 \mathrm{~cm}$ \\
\hline $\begin{array}{l}2 \text { irrigations at } 25 \text { and } 50 \text { DACR with } 80 \mathrm{~mm} \text { diw at each } \\
\text { irrigation }\end{array}$ & 13.6 & 19.2 & 22.4 \\
\hline $\begin{array}{l}2 \text { irrigations at } 25 \text { and } 75 \text { DACR with } 60 \mathrm{~mm} \text { diw at each } \\
\text { irrigation }\end{array}$ & 19.6 & 28.6 & 33.1 \\
\hline $\begin{array}{l}3 \text { irrigations at } 25 \text { and } 50 \text { and } 75 \text { DACR with } 60 \mathrm{~mm} \text { diw at } \\
\text { each irrigation }\end{array}$ & 14.7 & 17.6 & 23.2 \\
\hline S.Em. \pm & \multicolumn{3}{|c|}{0.5} \\
\hline $\mathrm{CD}(\mathrm{P}=0.05)$ & \multicolumn{3}{|c|}{1.8} \\
\hline C.V.\% & \multicolumn{3}{|c|}{4.7} \\
\hline
\end{tabular}

Note: DACR: Days After Cessation of Rainfall 


\section{Soil moisture studies}

Significantly the highest effect on water expense efficiency was observed scheduling of two irrigations at 25,75 days after cessation of rainfall with $60 \mathrm{~mm}$ diw at each irrigation because less quantity of water use which is $120 \mathrm{~mm}$ results in highest water expense efficiency. Since increasing \% water quantity provides wet surface for longer periods and consequently greater would be the loss due to evaporation. More frequently irrigated crop had profuse vegetative growth led to more transpiration resulting in more consumptive use. Whereas, reverse trend was observed in case of water use efficiency because of limited irrigation water in which less amount of available soil moisture was more efficiently utilized for crop yield. These finding are on the line with the results of Doss et al., (1964), Cull et al., (1981), Khade et al., (1988) as well as Singh and Bhan (1993a).

\section{Interaction effects}

\section{Interaction effect on seed cotton yield}

Tillage depth upto $22.5 \mathrm{~cm}$ coupled with three irrigations at 25, 50 and 75 days after cessation of rainfall with $60 \mathrm{~mm}$ diw at each irrigation) recorded significantly higher (4189.69 $\mathrm{kg} \mathrm{ha}^{-1}$ ) seed cotton. Deep tillage along with appropriate irrigation water at proper stage with right quantity provided nutrient from deep root zone and longer period of crop life which reflected in better growth and development of plant and ultimately resulted in increased seed cotton yield. Singh and Singh (2000) as well as Balkcom et al., (2006) reported similar results in cotton crop (Table 3).

\section{Interaction effect on water expenses efficiency}

Tillage depth upto $22.5 \mathrm{~cm}$ coupled with three irrigations at 25, 75 days after cessation of rainfall with $60 \mathrm{~mm}$ diw at each irrigation) recorded significantly the highest $(33.14 \mathrm{~kg}$ ha $\mathrm{mm}^{-1}$ ) water expense efficiency (Table 4).

\section{References}

Adeoye KB, 1982. Effect of tillage depth on physical properties of a tropical soil and yield of maize, sorghum and cotton. Soil and tillage Res: 2 (3):225-231.

Baker HS, 1987. Effect of tillage practices on cotton double cropped with wheat, Agronomy Journal; 79: 513-516.

Balkcom KS, Reeves, DW, Shaw JN, Burmester CH and Curtis LM 2006. Cotton yield and fiber quality from irrigation tillage system in the Tennessee valley, Agronomy Journal; 98: 596-602.

Chimanshette TG, Hudge VS and Shelke VB 1990. Association of yield parameters with seed cotton yield under protective irrigation and fertilization, Annuals of plant physiology; 4(2): 22-28.

Cull PO, Hearn AB and Simth RC, 1981. Irrigation scheduling of cotton in a climate with uncertain rainfall. Irrigation Science; 2 127-140.

Doss BD, Ashely DA and Bennett OC 1964. Effect of moisture regime and stage of plant growth on moisture use by cotton, Soil Science; 98 (3) 156-161.

Gidda VP and Morey DK, 1981. Effect of tillage practices and anti-transpant on relative water content leaf water potential and yield of rainfeed cotton (SRT-1) Journal of Maharashtra Agricultural Universities; 6 (3) : 219220.

Khade KK, Shinde SH, Pawar HK and Umrani NK, 1988. Effect of scheduling of irrigation for cotton Journal of Maharashtra Agricultural Universities; 3 (1): 65-67.

Nayakatawa EM and Reddy KC, 2000. Effect of tillage cover cropping, and poultry litter effect on cotton gernination and 
seeding growth, Agronomy Journal; 92: 9922-999.

Palchamy A, Sundarsing SD and Ranjagopal A 1986. Effect of water management in pure and intercropped stand of MCU.9 cotton, Madras Agricultural Journal: 73 (11): 655-656.

Sing RP and Bhan S 1993a. Effect of irrigation and moisture conservation practice on growth yield and quality of cotton (Gossypium species) as summer and rainy season crops in central Uttar Pardesh frequency of irrigation and moisture conservation practices, Indian Journal of Agronomy ; 38(1): 82-88.

Sing RP and Bhan S, 1993b. Effect of yield quality and economics of summer cotton as influenced by frequency of irrigation and moisture conservation practices, Indian Journal of Agronomy ; 38(3): 439-442.

Sing V and Sing V 2000. Effect of tillage practices and irrigation levels no growth and yield of American cotton grown after wheat, Indian Journal of Agriculture science; 70 (8): 538-5540.

Solaiappan U and Sheriff NM, 1994. Effect of tillage practices and nitrogen application in cotton grown after rice Indain Journal of Agronomy; 39(2): 302-304.

Stockon JR, Doneen LD, Walhood VT, 1961. Boll Shedding and growth of the cotton plant in relation to irrigation frequency, Agronomy Journal; 272-275.

Triplett GB, Danbney SM and Siefker JM, 1996. Effect of tillage system for cotton on upland soil, Agronomy Journal; 88(4): 507-512.

Wiatrack PJ, Wright DL, Marosis JJ Koziara $\mathrm{W}$ and Pudelko JA 2005. Tillage and nitrogen application impact on cotton following wheat, Agronomy Journal; 97: 288-292.

\section{How to cite this article:}

Bagal, V.T., A.J. Madane, R.A. Gaikwad, R.R. Sisale, P.U. Lawate, V. Akhilesh and Singh, J.K. 2018. Response of Cotton to Different Tillage Depth and Irrigation Levels in Southern Gujarat. Int.J.Curr.Microbiol.App.Sci. 7(02): 602-609. doi: https://doi.org/10.20546/ijcmas.2018.702.075 